\title{
Labor Commodification in the Sugarcane Plantations of Alagoas, Northeast Brazil
}

\author{
Allan S. Queiroz
}

Keywords: Brazil, sugarcane cutters, labor commodification, labor reform, precarity

$\mathrm{I}$ n 2018, an opinion piece in the newspaper Folha de São Paulo questioned 'Should we prohibit the poor from having degrading jobs?' The article was a reaction to the shutdown of a flour factory in the state of Alagoas, Northeast Brazil, on which labor authorities found 87 people working in conditions analogous to slavery. For the author, cutting labor rights and protections would benefit the working poor with job creation, implying that they should be forced to accept any working conditions to make ends meet. In colonial Brazil, too, workers were forced to work under painful conditions, the difference being that they were enslaved subjects. This seemingly innocent defense of the exploitation of the poorest reveals the challenges that workers face under contemporary capitalism in Brazil, where the frontiers of labor commodification ${ }^{1}$ are being pushed far below the line of human dignity.

Since the interim government of Michel Temer approved the Labor Reform (Law 13. 467 ) in 2017, it has become cheaper to hire and fire workers. The reform consisted of a downward regulatory overhaul that modified more than 100 articles $^{2}$ of the 1943

Consolidation of Labor Laws (CLT by its acronym in Portuguese), Brazil's legislation regulating capital and labor relations until the day. CLT has never been applied in its entirety, neither in urban nor rural Brazil. The country's ruling classes have always disputed labor regulations and protections with the complicity of state authorities. Since the election of Jair Bolsonaro in 2018, they reorganized themselves around an authoritarian project of power, which is widely backed by agribusiness and industrialists, given Bolsonaro's promises to boost market freedoms by reducing social and labor rights. Here I focus on the case of the sugarcane plantations of Alagoas, Northeast Brazil, where I have been carrying out fieldwork since 2012 to explore a couple of questions around labor precarity and job formalization using oral history interviews, documents, and labor process observations. Between May and August 2019, I returned to the field to undertake exploratory fieldwork about the consequences of the labor reform in terms of the working conditions and rights of the sugarcane cutters.

Brazil's sugarcane cutters and have never experienced a process of labor decommodification. The sugarcane agroindustry that employs cane cutters has historically used patterns of labor exploitation and immobilisation (slave, tenant and flexible, informal labor) under deregulated conditions that linked the right to survival to degrading labor. With the transition to a 'free labor' society in the nineteenth century, and in anticipation of the 1888 Abolition, rising concerns with disciplining rural workers appeared in the transcripts of Alagoas' first agricultural association in 1877. Landowners demanded repressive measures to curb the

\footnotetext{
${ }^{1}$ By labor commodification I understand the capitalist wage work relationship whereby dispossessed workers are dependent upon the sale of their labor power for their survival.

2 In total, 106 articles were modified: 54 were amended, 43 new ones inserted and 9 revoked. See Confederação Nacional da Indústria. 2018. Modernização trabalhista: lei no 13.467 de 13 de julho de 2017, panorama anterior e posterior à aprovação. Brasilia: CNI.
} 


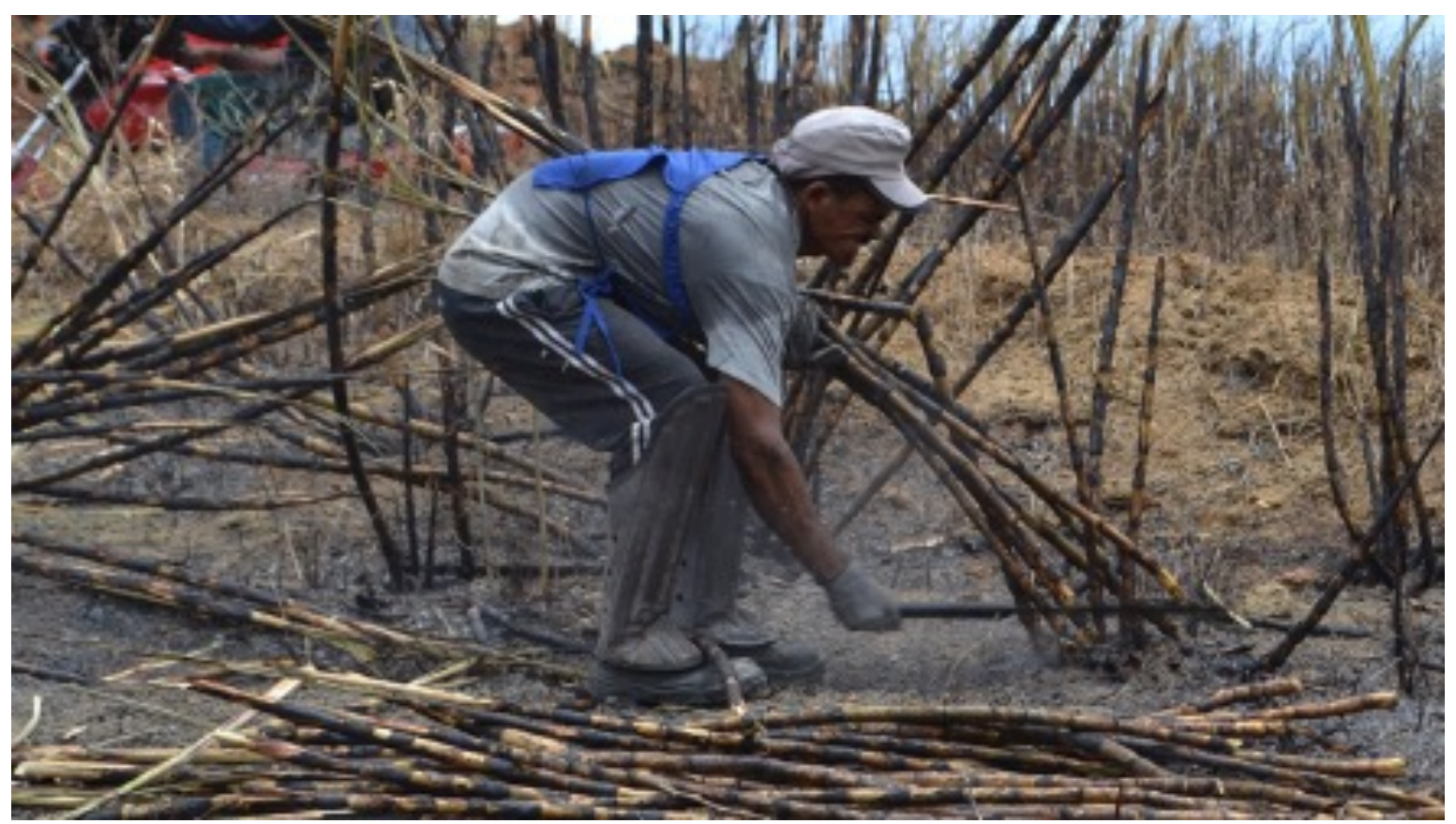

The mills closely control the labor process and expect cutters to strike the cane at ground level, as the highest amount of sucrose is in the lower part of the plant. Repetitive movements during cane cutting generate many musculoskeletal disorders among rural workers. Source: Allan S. Queiroz, 2013.

free movement of labor and attests of moral and civic behavior from those workers hiring out their labor to the plantations (Manuel Diégues Jr. 2012). Slaves were gradually replaced by tenants who exchanged labor for a residence with access to a plot of land, on the condition that they were unrestrictedly subordinated to the labor demands of the landowners. Thus, the landowning capitalist class in the Northeast of Brazil adopted the system of morada, which incorporated tenant workers as a source of cheap, dependable, and controllable labor. These tenants or moradores formed a specific type of rural proletariat that became 'immobilized' through moral and economic debts and had barely no access to social or labor rights (Heredia BMA de 1988; Heath 1981).

Although the CLT already granted rights to rural workers, and in 1963 a specific legislation extended more rights and protections, in fact, these regulations were almost never applied nor enforced in rural Brazil. Rural workers made several organizational efforts for better working and paying conditions and access to land in the 50 s and 60s, such as the Peasant Leagues, which were crushed by the 1964 dictatorship. At that time, the various segments of the agrarian ruling class - senhores de engenho (traditional landowners) and usineiros (capitalists concentrating land and industry) waged a dispute for power and resources in line with state-sponsored modernizing projects during the 1970s and 1980s. The dispute culminated with the dissolution of labor tenancy relations, the expansion of plantations tied to the modern sugar mills (usinas) and the utilization of informally hired, unprotected casual labor. Despite the noncompliance with labor laws, the sugarcane agro-industry was considered 'the most important historical experience of state intervention in a set of activities in Brazil' since the creation of the Institute of Sugar and Alcohol in 1933 (Ramos 1999). That is, in the course of the twentieth century, the Brazilian state intervened and subsided the expansion of the plantations and capital accumulation at the expense of the rights and protections of rural workers.

Under the 1988 Constitution, it was no longer possible to ignore that rural workers were subjects with rights: constitutional social and labor rights were equalized for both rural and urban workers. After decades of informal jobs, the rising job formalization of the 1990s became associated with better wages, benefits, and entitlements to social protection.

However, cane cutters also saw their work effort quadruplicate in the following decades. The sugarcane agro-industry raised the bar of 
work effort using piece wages and a series of incentives to increase workers' output.

Around 2008, the 'National Agreement to improve working conditions in sugarcane' promised to extend new rights and a better quality of life for sugarcane workers. The agreement responded to the numerous deaths by overwork in São Paulo's plantations, Brazil's largest sugar and ethanol producer (Alvez 2006). Most claimed lives were of migrant workers coming from Northeast Brazil. At the same time, the agreement was an attempt by the Brazilian state and agroindustrial capital to clean up the image of Brazilian commodities in global markets. However, the situation of precariousness and super-exploitation of labor underlying ethanol and sugar production was kept intact. The agreement expired in 2012, upon which São Paulo and the other largest producing states in Brazil speeded up the harvest's mechanization, replacing people with machines. But in Alagoas, the harvest remains mostly done by manual labor.

Alagoas' rural workforce is hired through formal contracts to cut sugar cane manually from September to March. Rural workers can only keep their jobs if they attain high production quotas. While they used to cut between one to two tons of cane as informal workers in the past, they are now expected, as formal workers, to cut above four to seven tons per day. Many cutters, however, surpass those exigencies to make better wages. Piece wages lead to a critical situation in which you are convinced that 'the more you cut, the more you earn'. As a result, work accidents and work-related illnesses became endemic in the sugar industry. Occupational illnesses include a generalized cramp that might lead to death, which the Alagoas' workers dubbed 'kangaroo' (Queiroz and Vanderstraeten 2018).

Most of the men and women that I have interviewed over the years consider themselves biographically as rural workers. Their carteiras de trabalho, a Brazilian document that became a symbol of citizenship and formal employment, display that they have been incorporated into this sector as 'permanently temporary' workers. Their work cards are filled with years of temporary jobs on the plantations, revealing their precarious access to social and labor rights. The patterns of precarious employment are combined with recurrent unemployment and gaps in pension contributions. In other words, job formalization has meant a process of incorporation into a precarious citizenship. Moreover, due to the practiced piece wages, which in the plantations reflects the extraction of surplus-value based on the intensification of work, job formalization has been accompanied by a more intensive and health-threatening commodification of labor.

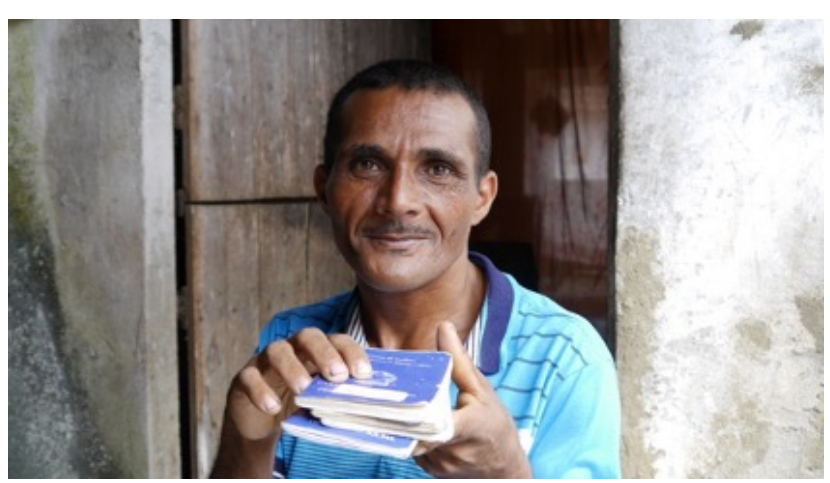

Mr João and his four work cards documenting his working life in the plantations. Source: Allan S. Queiroz, 2015.

Cane cutting is a backbreaking, labor-intensive activity and the seasonal cutters receive not more than one and a half minimum wage monthly. Given the seasonality of sugarcane harvesting, the cutters also experience recurrent unemployment during the slack season, creating many insecurities for them and their families. In 2011, Alagoas' sugarcane workers mobilized to fight the precarity of rights imbued in their work contracts. By law, seasonal contracts are terminated without social protection at the end of the harvest. That year, sugarcane workers held numerous road blockages to fight for more rights and protections in the period of unemployment. They interrupted the feeding of the mills crushing the cane to produce sugar and the transport of sugar to the port of Maceió. Consequently, the blockades disrupted both the production and the shipment of commodities to global markets, affecting the mills' profits.

In response to labor unrest, the mills implemented new hiring strategies to reach a labor compromise. They started signing fulltime contracts, which were forcibly 


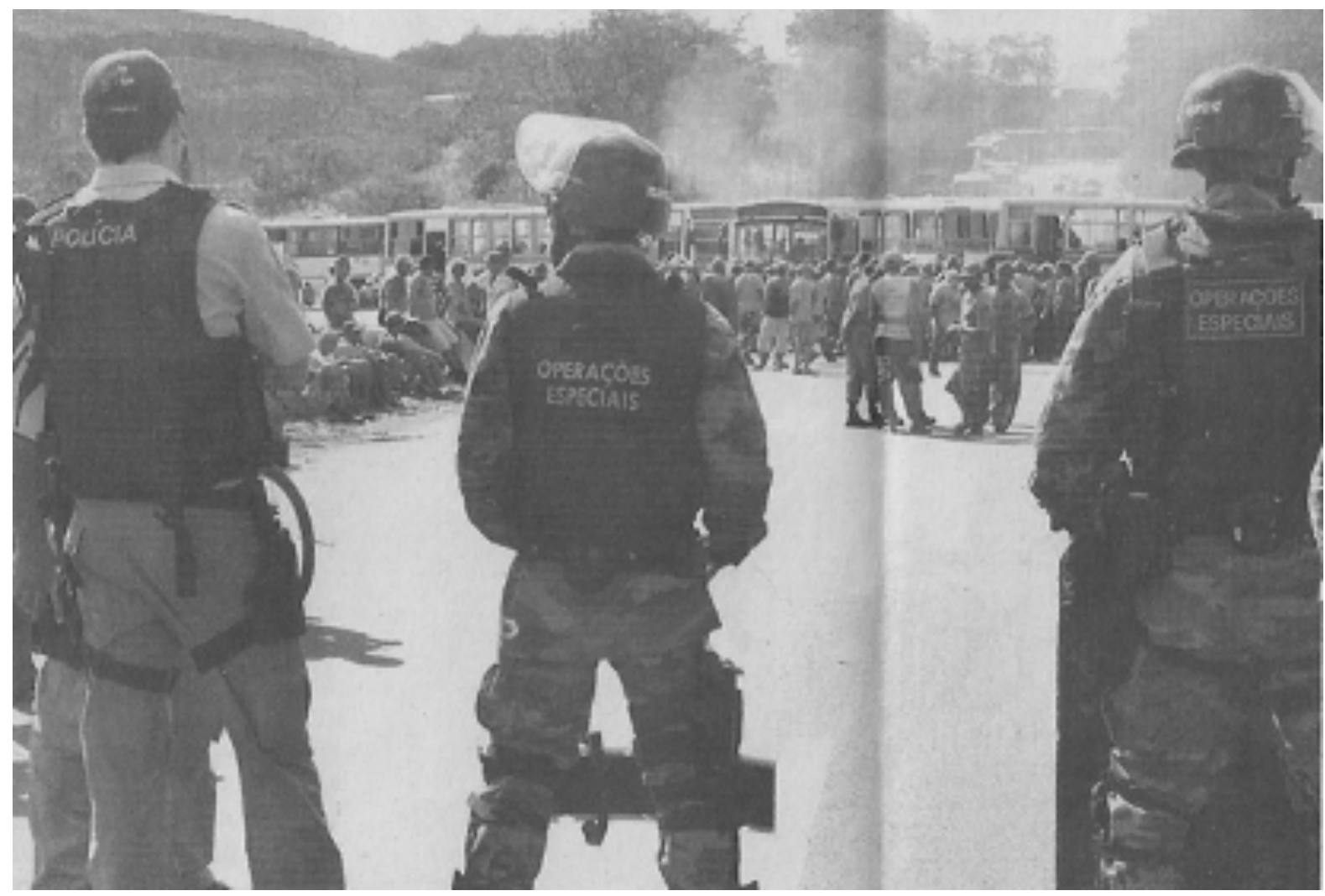

Cane cutters blocked a road near the plantations of Usina Seresta. In the last decade, wildcat strikes, road blockages, and work stoppages were common forms of collective action undertaken by sugarcane workers against their precarious situation. Source: Patricia Bastos, 2011. Image reproduced with permission.

terminated by the end of the harvest.

Seasonal workers accessed more rights and unemployment insurance and could guarantee food security for their families for a few months during the offseason. Such 'innovations', which had been considered fraudulent by the Ministry of Labor and Employment (MTE), led to a situation in which social protection mechanisms intensified the work effort in the plantations. Because the unemployment insurance was calculated based on the last wages received, workers began to expend greater physical effort to receive higher benefits, which increased the already high workloads to which they are exposed in the cane fields.

During the fieldwork, I observed that workers and their families had suffered many losses due to the Labor Reform. The cutters are now experiencing unfair wage deductions, underpayment, and more difficulties in accessing occupational health and safety at the workplace. In the plantations of a large sugar mill, workers have to produce 85 tons of cane cut in a fortnight to receive their weekly rest. That is, they must cut on average seven tons per day, from Monday to Saturday; otherwise, the mill steals their benefit. There are also quotas for doctor visits. Moreover, they are also working longer hours (above 44 hours) without overtime pay and experiencing delays in the payment of wages and severance provisions. According to the president of Alagoas' Federation of Rural Workers (FETAR/AL), Antônio Torres, some sugar mills are now paying wages below the minimum stipulated by the legislation and abusing labor outsourcing, which was prohibited in the plantations until recently (Interview with Mr. Torres, 2019). The reform wielded much power to employers who already counted with a series of mechanisms to extract surplus value from rural workers under degrading working conditions.

It is well known that an authoritarian labor politics prevails in the sugarcane plantations of Alagoas. Workers often relate a series of harassments, abuses and coercion at work. Those voicing their grievances are fired and blacklisted. Workers are also expected to comply with productive expectations; otherwise, they are sacked. In the isolation of the plantations, law and rights cease to exist, 
and managerial despotism prevails. One cane cutter experienced a series of intimidations and was coerced to cut cane in undesirable circumstances. The mill's agricultural manager forbade him to jump back on the bus if he did not cut the cane. That day, he said, 'I was forced to work'. After a series of dissatisfactions at work, toiling under extreme conditions, he had a stroke. For him, 'the only right we have is the right to work'. That is not an isolated case. Although it has become extremely challenging to undertake fieldwork in Alagoas' plantations, once you establish trust relationships, the very interviewing process becomes an encounter during which rural workers voice their discontent about unfair labor management practices and exploitation.

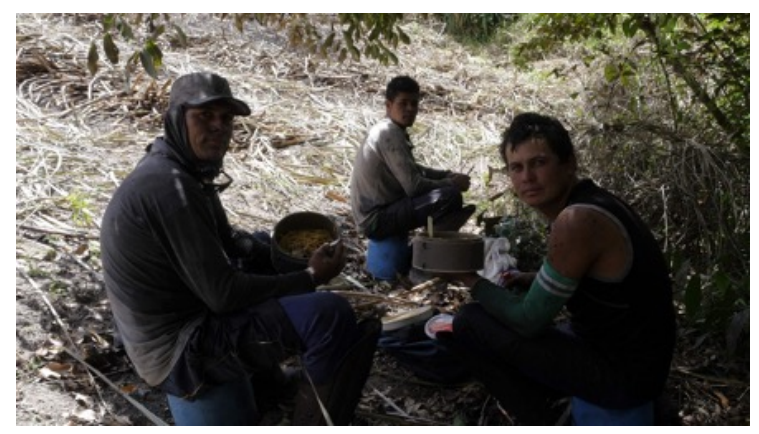

Cane cutters enjoy a lunch break under a tree. Without proper accommodation, they sit on their thermal bottles. Source: Allan S. Queiroz, 2015.

The reform also increased the unpaid work time. For example, commuting time (horas in itinere), a time during which workers were legally considered to be at the employer's disposal, is no longer paid. According to one cane cutter, the loss corresponded to a drop in $5 \%$ of his paycheck. This is not only an extension of the unpaid work over the working day, but it is also a precarization of working conditions. During commuting, often done through buses in poor conditions, many fatal accidents occur every year. Now, employers can claim they are no longer responsible for workers' lives during commuting time.

With the Labor Reform and other downward regulatory shifts ongoing in Brazil, what is at stake is the expansion of the frontiers of labor commodification. Workers sell their labor power under flexibilized and cheapened conditions, with fewer rights and entitlements to pension, and become increasingly dependent on employers as well as vulnerable to market forces. The job creation argument used to approve the Labor Reform was mismatched by the statistics, which show that Brazil's labor market is now primarily creating 'intermittent' jobs. (Folha de S. Paulo 2021). This new modality allows employers to hire out workers with no guarantee of a minimal number of working hours and income. That is, the reform institutionalized conditions to expand the working poor; those who despite their access to paid work remain under the poverty line. Notwithstanding the race to the bottom in terms of labor exploitation brought about by the reform, I believe the counterpoint is being built by the social experiences in the heart of Alagoas' plantations. For instance, rural communities are now occupying the lands previously explored by industrial agriculture and recreating the plantations as spaces of agroecology.

Various social movements that struggle for land rights and agrarian reform in Alagoas, including the Landless Rural Workers Movement (MST) and the Pastoral Land Commission (CPT), occupied the lands of the bankrupt Usina Laginha in 2013 (Uol Notícias 2018). Laginha was owned by João Lyra, who was once Brazil's richest member of Parliament, worth an estimated $\$ 140$ million, that subjected workers to modern-day slavery (Nova Cana 2014) and was exposed by the Panama Papers. Laginha's lands were repurposed into family agriculture, and it now benefits about 10 thousand peasants, including former sugarcane workers. Once occupied by plantations serving global markets, the land now supports the communities cultivating it and the local markets. The settlement conditions are far from ideal, but the peasants now have a place to call home and land access to cultivate subsistence plots, commercialize surpluses, and push demands for agrarian reform of those lands. This is only one example of labor decommodification amidst a context of setbacks in social, labor, and agrarian reform policies set in motion by the Bolsonaro government.

Long before the advance of sugarcane fields over the Zona da Mata region of Alagoas in the twentieth century, that land now occupied 
by peasants saw the rise of the most significant struggle for freedom in Brazil. The Quilombo dos Palmares was a rebel polity constituted by runaway slaves from the late sixteenth through the seventeenth century that resisted colonial oppression for more than 100 years. Fast forward to the present, former wage workers are now growing their food after liberating themselves from the exploitation of their labor under intensified conditions. This echoes the past struggles for freedom and justice rooted in that territory and serves as a basis for transforming the future. At a time when the ruling classes are pushing to remove social and legal barriers to the expansion of degrading work, the social struggles for land rights and an agrarian reform that works for the people that decouples survival, housing and food security from market constraints remains an essential alternative for a more socially just and equitable future in Brazil.

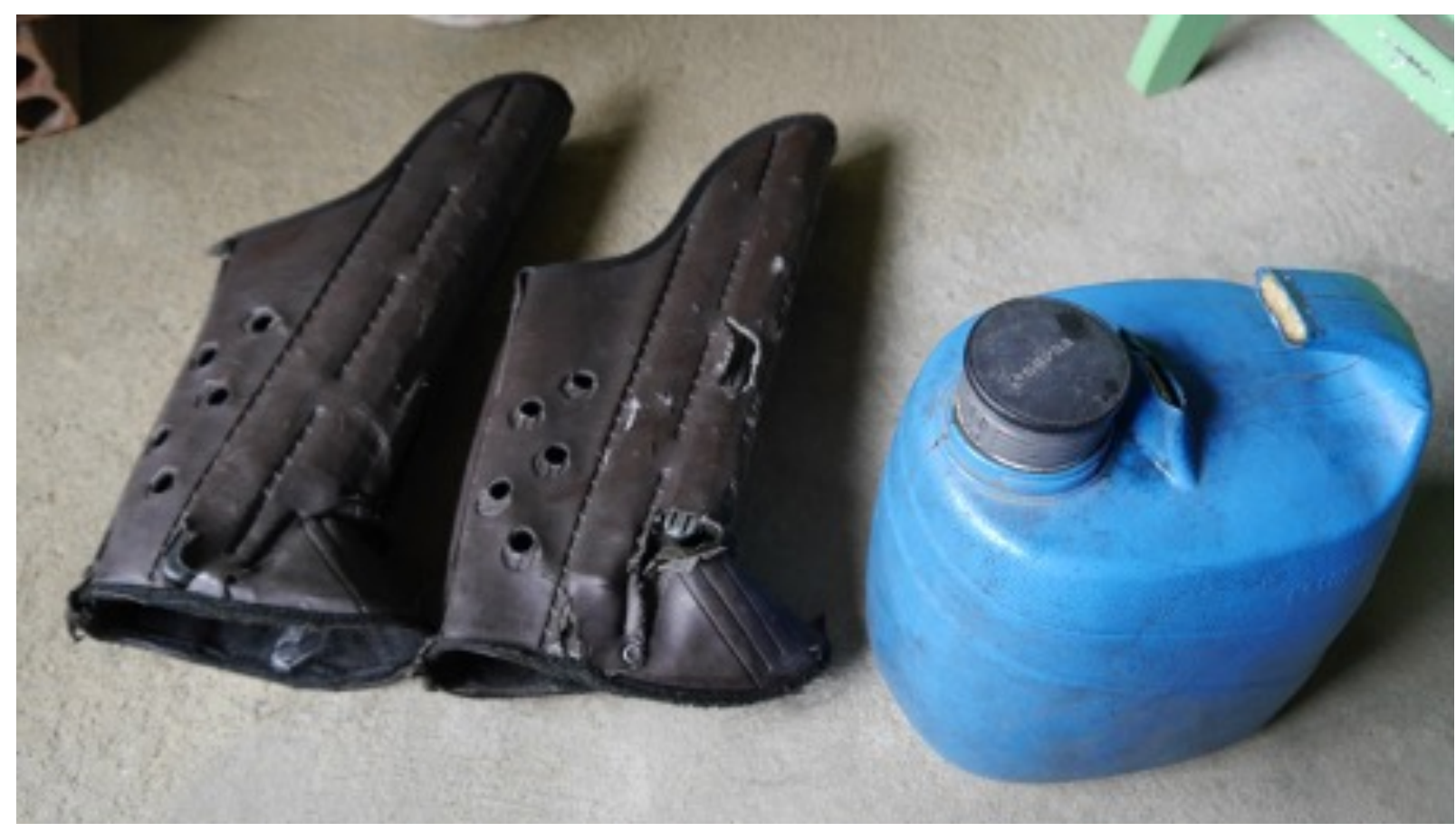

During an interview, a cane cutter showed his worn-out shin guards, a mandatory PPE in the cane fields, and a broken thermal bottle. Workers related many difficulties in having their PPE's replaced. Source: Allan S. Queiroz, 2015.

\section{References}

Alves, F. 2006. Por que morrem os cortadores de cana? Saúde e Sociedade 15(3): 90-98.

Folha de S. Paulo. 2021. Metade das vagas formais abertas em 2020 é de trabalho sem jornada e salário fixos. Available at: https://www1.folha.uol.com.br/mercado/2021/02/metade-das-vagasformais-abertas-em-2020-e-de-trabalho-sem-jornada-e-salario-fixos.shtml (accessed $8 \mathrm{March}$ 2021).

Folha de S. Paulo. 2018. Opinião - Leandro Narloch: Deveríamos proibir os pobres de ter trabalhos degradantes? Available at: https://www1.folha.uol.com.br/colunas/leandro-narloch/2018/05/ deveriamos-proibir-os-pobres-de-ter-trabalhos-degradantes.shtml (accessed 11 December 2020).

Heath, JR. 1981. Peasants or proletarians? Rural labor in a Brazilian plantation economy. The Journal of Development Studies 17(4): 268-281.

Heredia BMA de. 1988. Formas de dominação e espaşo social: a modernizaação da agroindústria canavieira em Alagoas. São Paulo: Marco Zero.

Manuel Diégues Jr. 2012. O bangüê nas Alagoas: traços da influência do sistema econômico do engenho de açucar na vida e na cultura regional. Maceió: EDUFAL. 
Nova Cana. 2014. STF abre ação penal contra usineiro dono da Laginha Agroindustrial por trabalho escravo. Available at: https://www.novacana.com/n/cana/trabalhadores/acao-penal-usineirolaginha-trabalho-escravo-210814 (accessed 10 August 2020).

Queiroz, A.S. and Vanderstraeten, R. 2018. Unintended consequences of job formalisation:

Precarious work in Brazil's sugarcane plantations. International Sociology 33(1): 128-146.

Ramos, P. 1999. A agroindústria canavieira do Brasil: referencial historiográfico, temas e fontes. América Latina en la Historia Económica 6(11): 59-71.

Uol Notícias. 2018. 'Cidades' de sem-terra. Available at: https://www.uol/noticias/especiais/usinareforma-agraria.htm (accessed 2 February 2021).

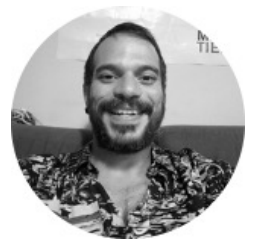

Allan Souza Queiroz is a $\mathrm{PhD}$ candidate at the Centre for Social Theory, Department of Sociology at Ghent University, Belgium.

*All photos provided by the author.

\section{Correspondence:}

Allan Souza Queiroz, allan.souzaqueiroz@ugent.be.

\section{Cite this article:}

Queiroz, A.S. 2021. "Global Commodities: Special Issue of the Austrian Journal of Historical Studies." Commodity Frontiers 2: 41-47. doi: 10.18174/cf.2021a18083.

Commodity Frontiers is an open-access journal edited by the CFI Editorial Board, Mindi Schneider, senior editor. Read it online at Commodity Frontiers, or our website, commodityfrontiers.com.

This work is licensed under a Creative Commons Attribution-NonCommercial 4.0 International License

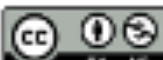

